\title{
Comparisons and Contrasts
}

Ding drew very similar cartoons for the first casualties of the two world wars. The first was drawn in memory of Merle Hay of Glidden, one of the first three American boys killed in World War I. [27] The cartoon by Ding appeared a few days after his death in November, 1917. A monument, standing along Highway 30 at Glidden, was erected by the State of Iowa in 1928 to commem orate Merle Hay's death. Ding's cartoon was reproduced on this monument. The road to Camp Dodge from Des Moines was named for Merle Hay. The wording on Merle Hay monument refers to his death "in the world war," as if there would not be a second. ... The cartoon for World War II appeared in 1942, on the first anniversary of the attack on Pearl Harbor-December 7, 1941. [28]

On another occasion, Ding drew similar cartoons on the deaths of two of his friends-Iowa statemen who had been serving in Washington for years. Henry Cantwell Wallace, second gen eration publisher of the Wallace's Farmer magazine, was in the cabinet of President Harding as Secretary of Agriculture at the time of his death in 1920. [29] Henry Agard Wallace, son of Henry 

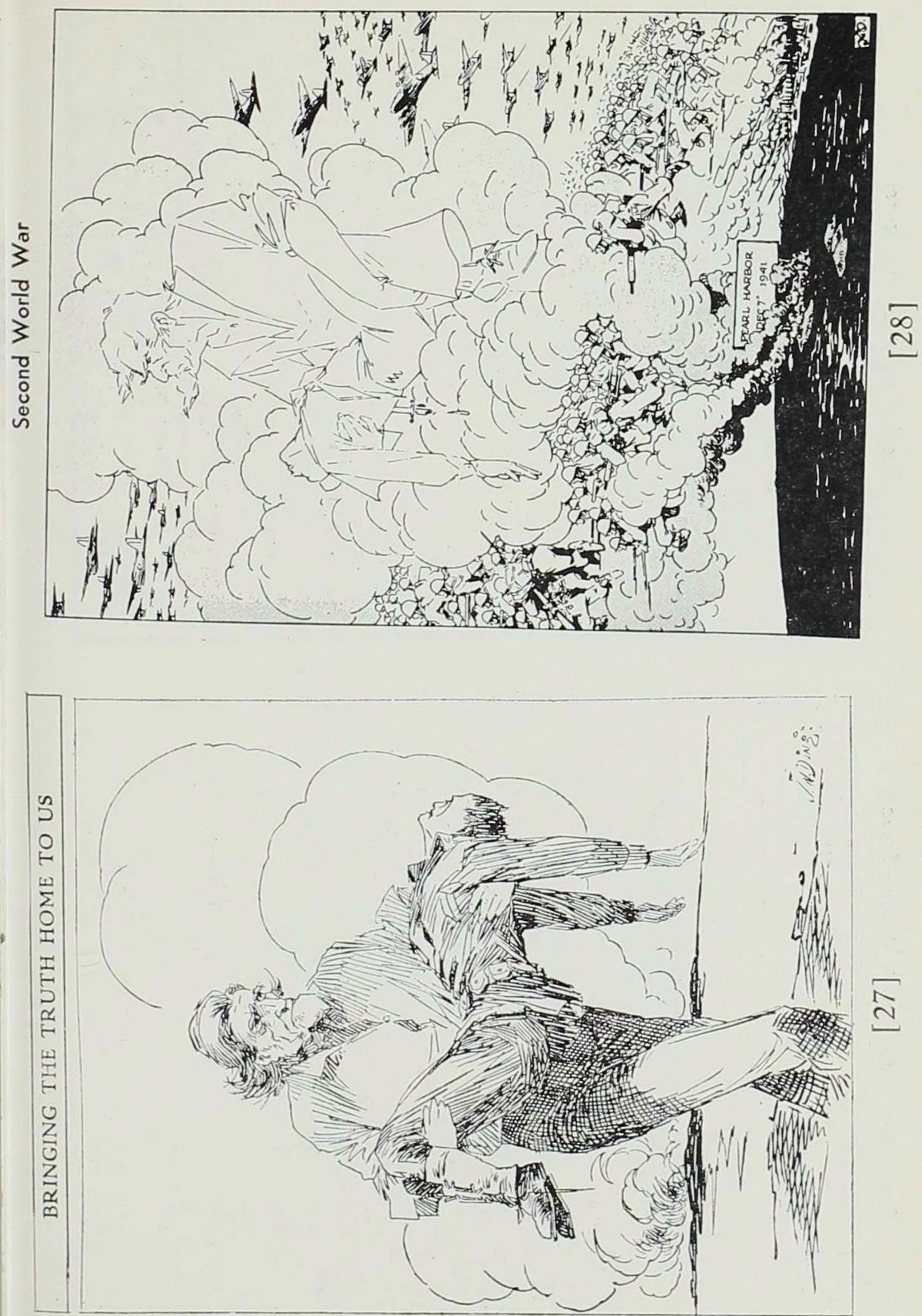

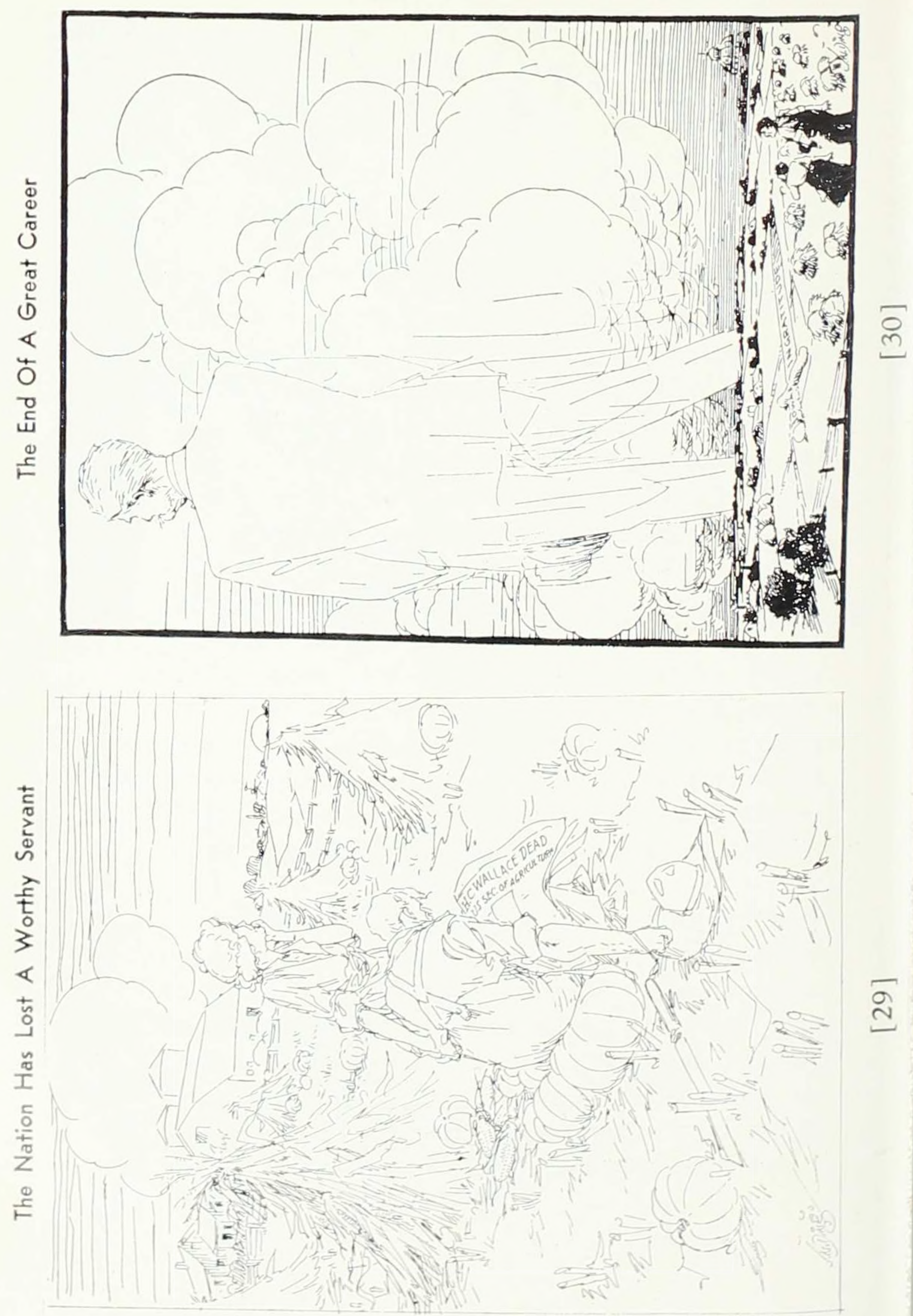

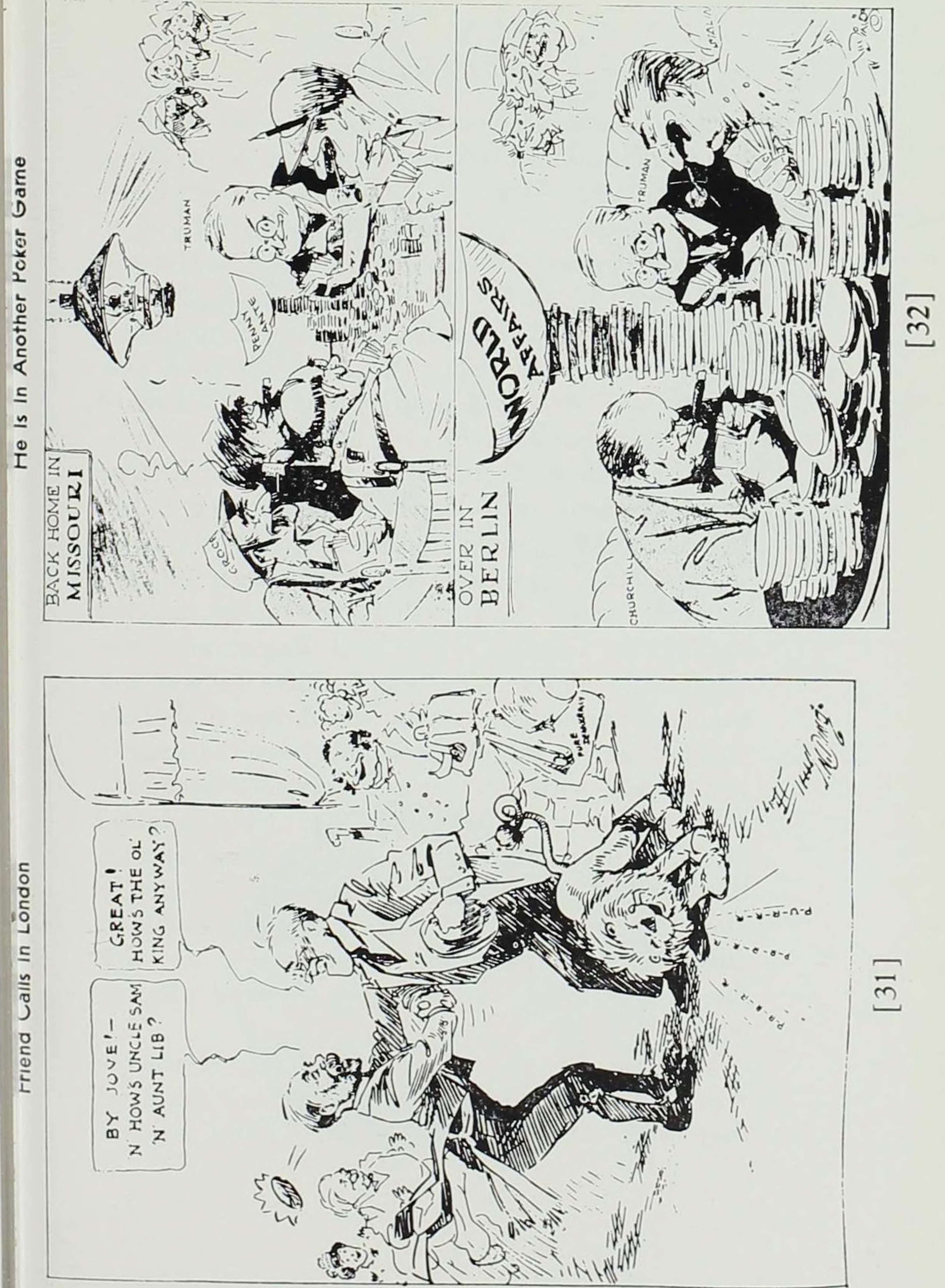
Cantwell, was Democratic Secretary of Agriculture for Franklin D. Roosevelt and vice president 1941 to 1945. Albert B. Cummins had served as Iowa's governor for three terms, then had gone to the United States Senate for three terms. His ma jority in 1920 was the greatest ever given an Iowa official. But the depression period on Iowa's farms in the early 1920's drew support from him, and he was defeated at the primary elections of June, 1926. He died the next month. [30]

Ding drew cartoons about the trips to Europe of two presidents-Wilson-immediately after World War I, and Truman immediately after World War II. Wilson was widely and wildly acclaimed, visited the British Royal family, headed parades in London, Paris and Rome, and was viewed by millions. This was because the war had been so thoroughly won by the Allies, and there was not, as yet, any dickering between them about what to do with the Central Powers-Germany, Austria, Turkey. That came later. (The original of the Wilson cartoon was said to have reached Buckingham palace.) [31] Whereas, immediately after the end of World War II the victors began dickering, and quarreling over what to do with the losers. Thus, Truman was depicted playing poker. [32]

Probably Ding's best known cartoon character was the Iowa fat farmer. Many Iowa men declared they were the model for that, but Ding insisted 


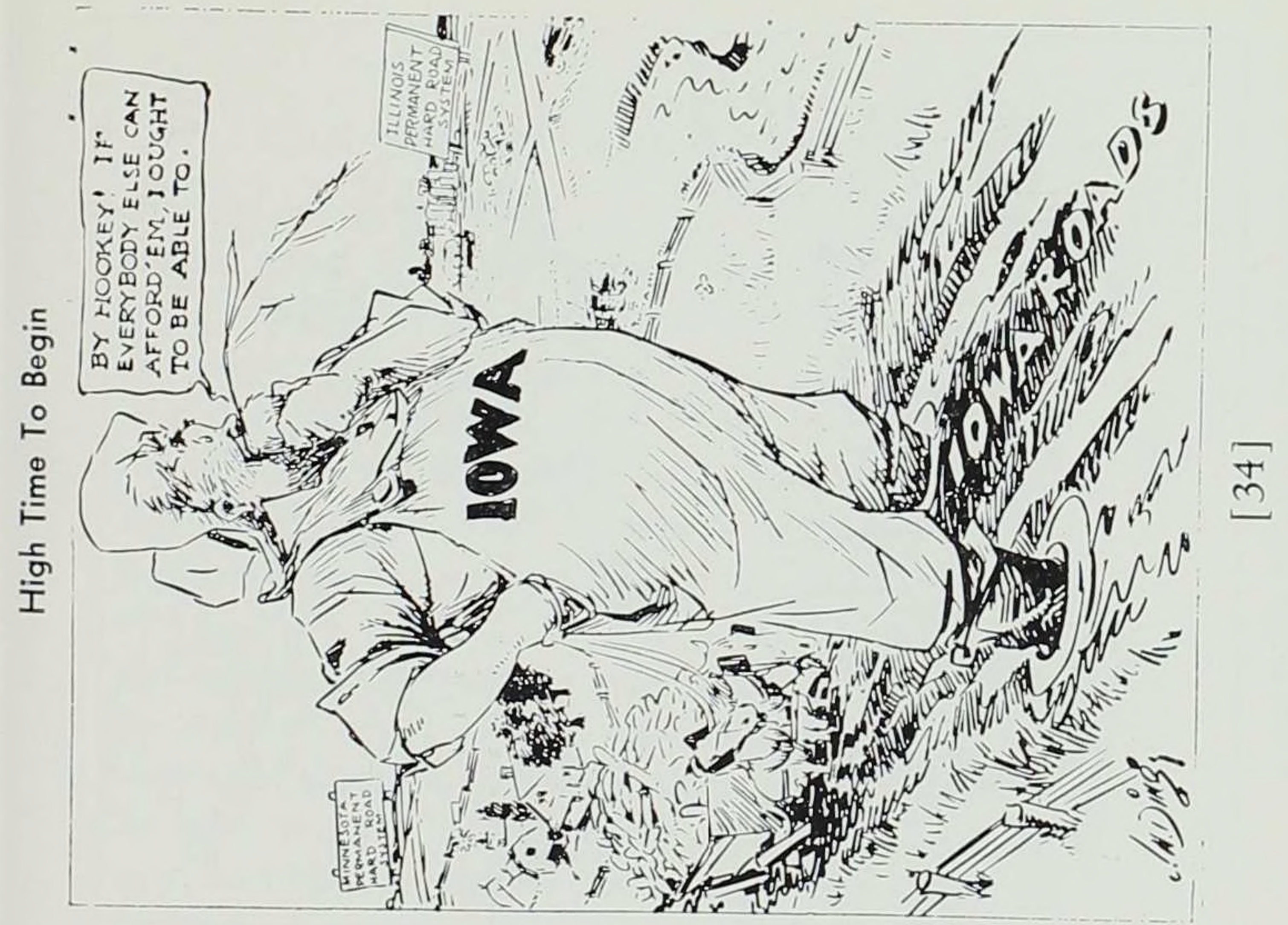

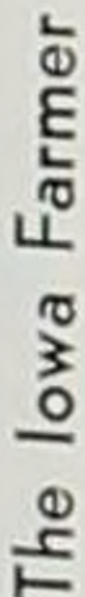

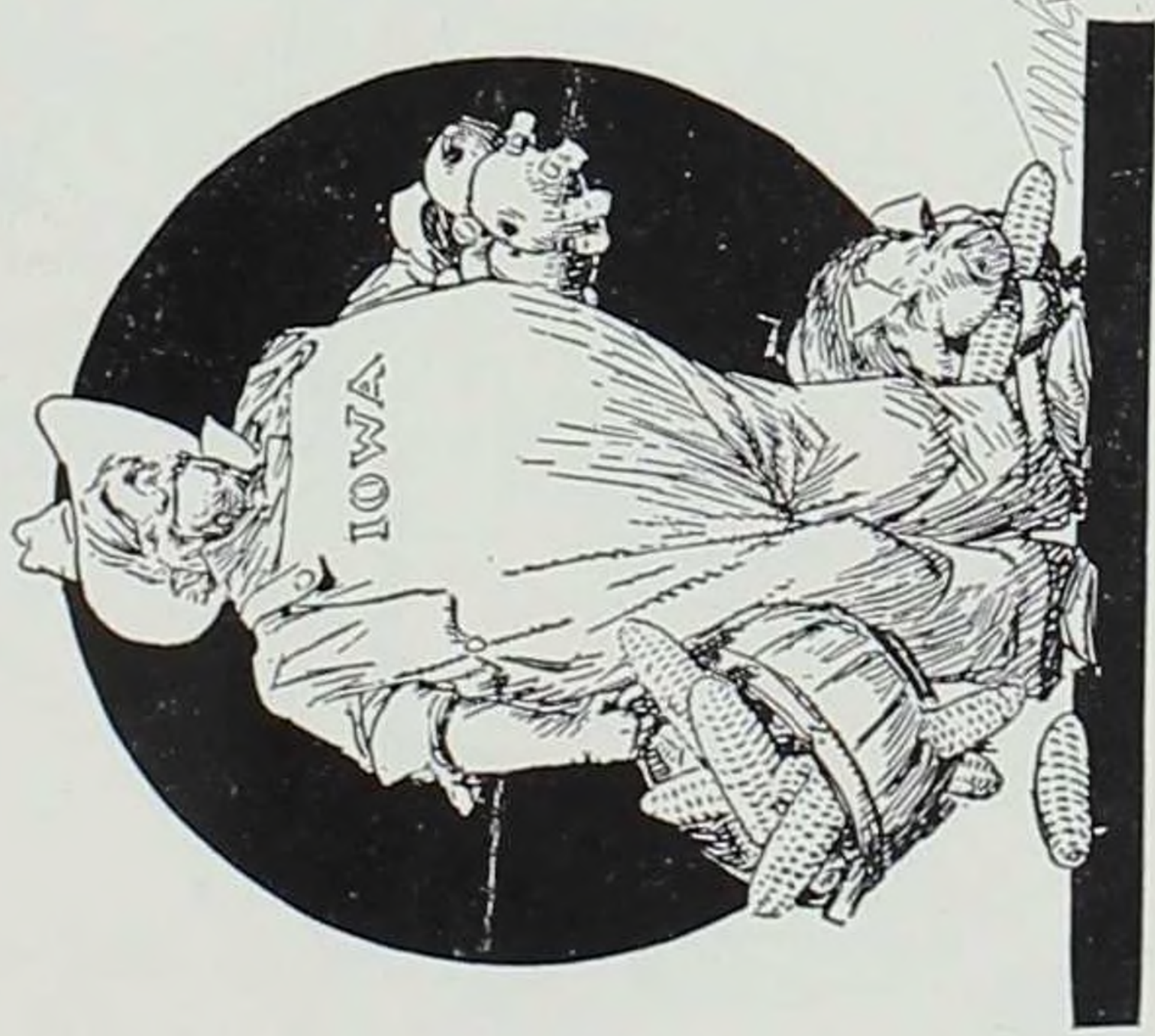




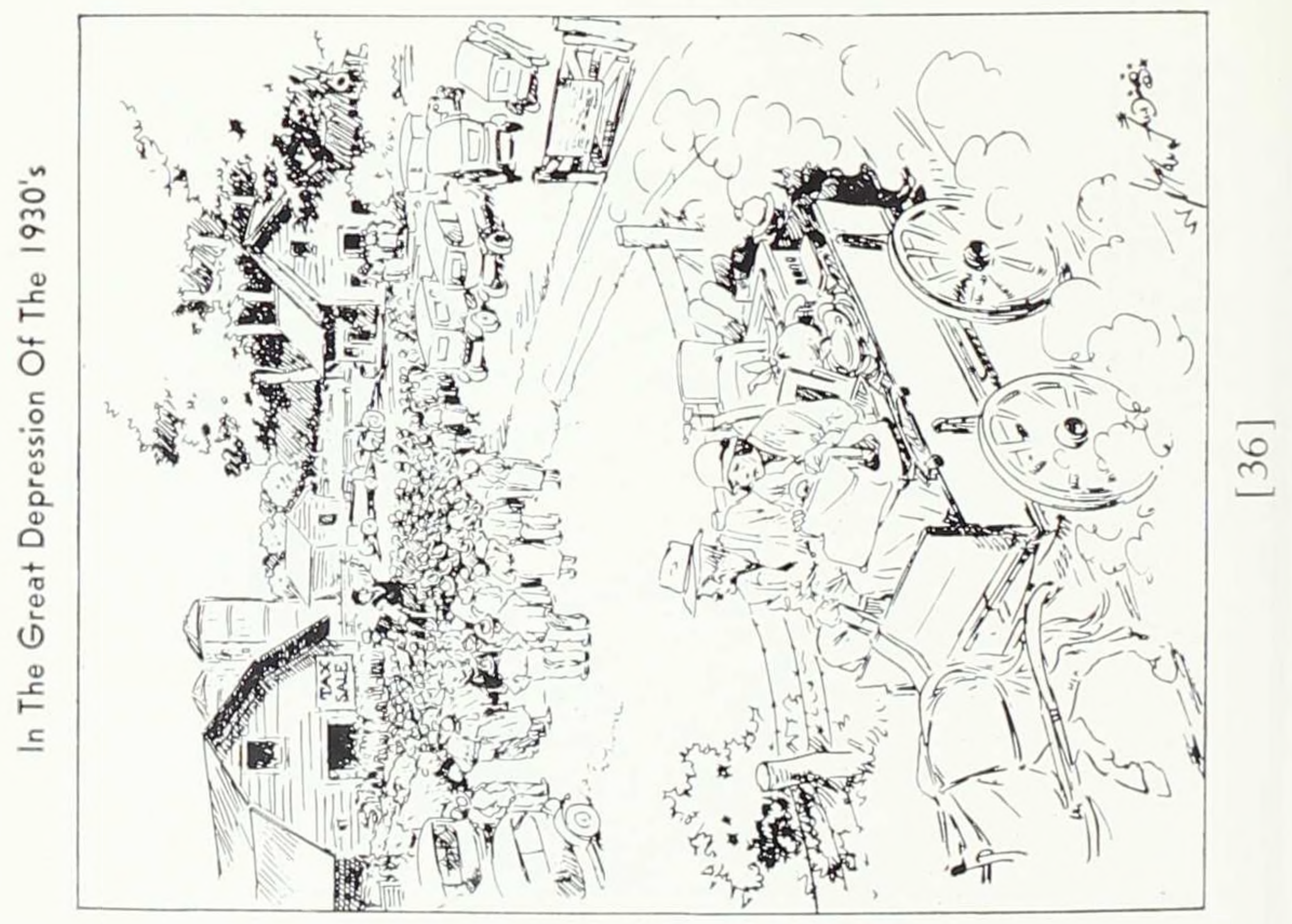

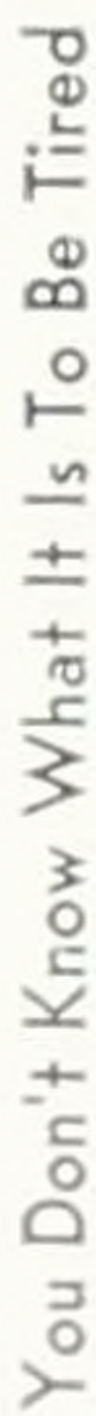

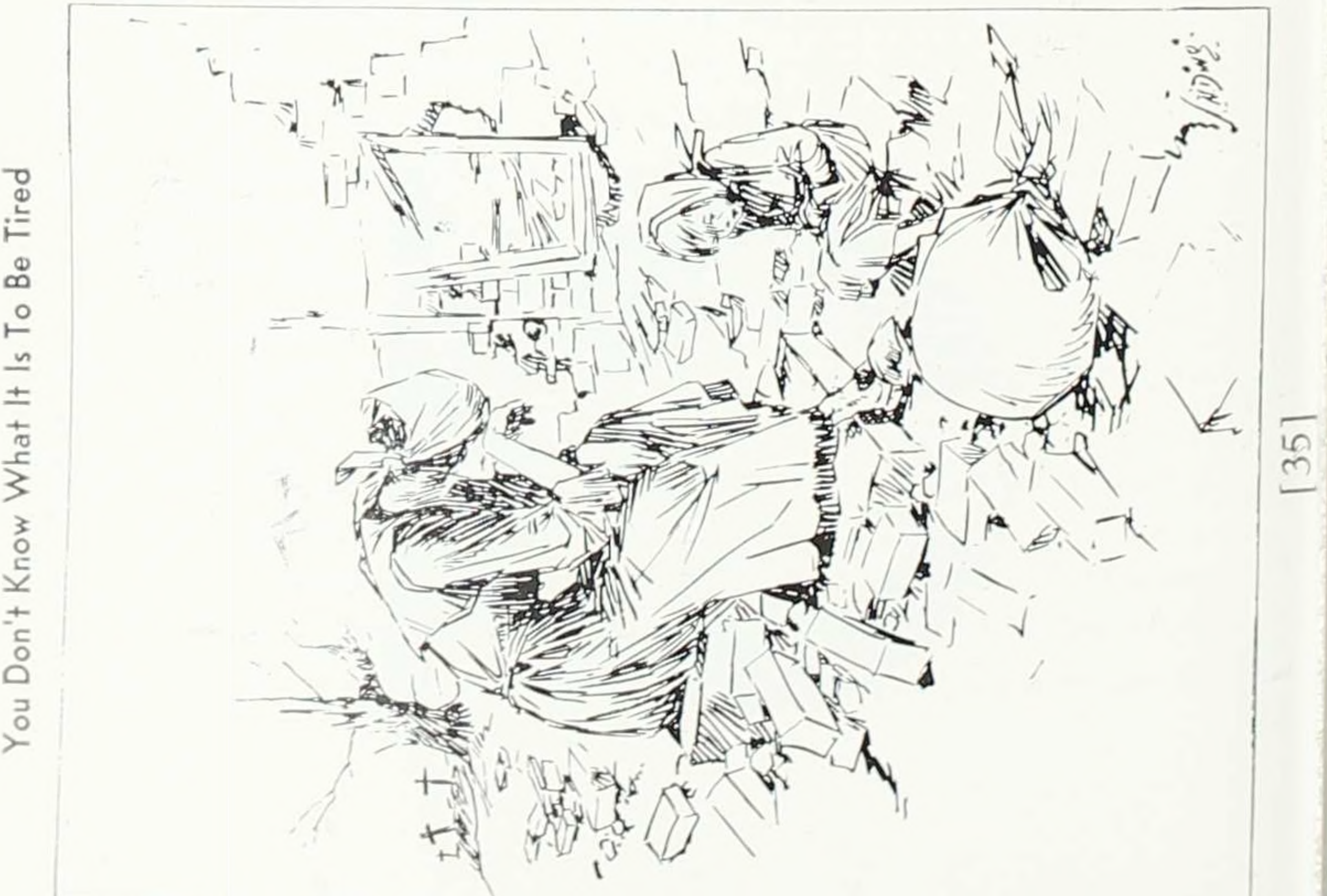


that no one man was the model. Ding drew his fat farmer most often as a single figure, looking happy. [33] But, at other times he put him into slightly rumpled workaday clothes, as at the right above, in a cartoon drawn in 1919. The fat farmer came off the drawing board the latter part of the teens. Before that, the Iowa farmer was just a sort of harassed rural person, worrying about the corn crop. [34]

Ding used the light touch nearly always in his cartoons. Very, very seldom was there rancor. But, now and then he did show deep feeling and then he was bitter. Once he drew a cartoon while an gry, and later he asked that this cartoon be shown in any collection of his work, with an explanation of why it was drawn. In Des Moines, one evening at a bridge game, he heard a woman say, during World War I, that she was "tired" of all the Red Cross, food-saving and such campaigns. Next day he drew the cartoon shown here, saying directly to the world- "You don't know what it is to be tired." [35] In the years after his retirement, a half a century later, he said, "I'm still mad at that woman." In contrast to his "mad" cartoon was a "sad" one he produced during the Great Depression of the 1930's. That was a sad period, and Ding enlivened it some with his pen, but he conscientiously recorded the "sad" part of the history. [36]

In the half century of Ding's cartoons woman 

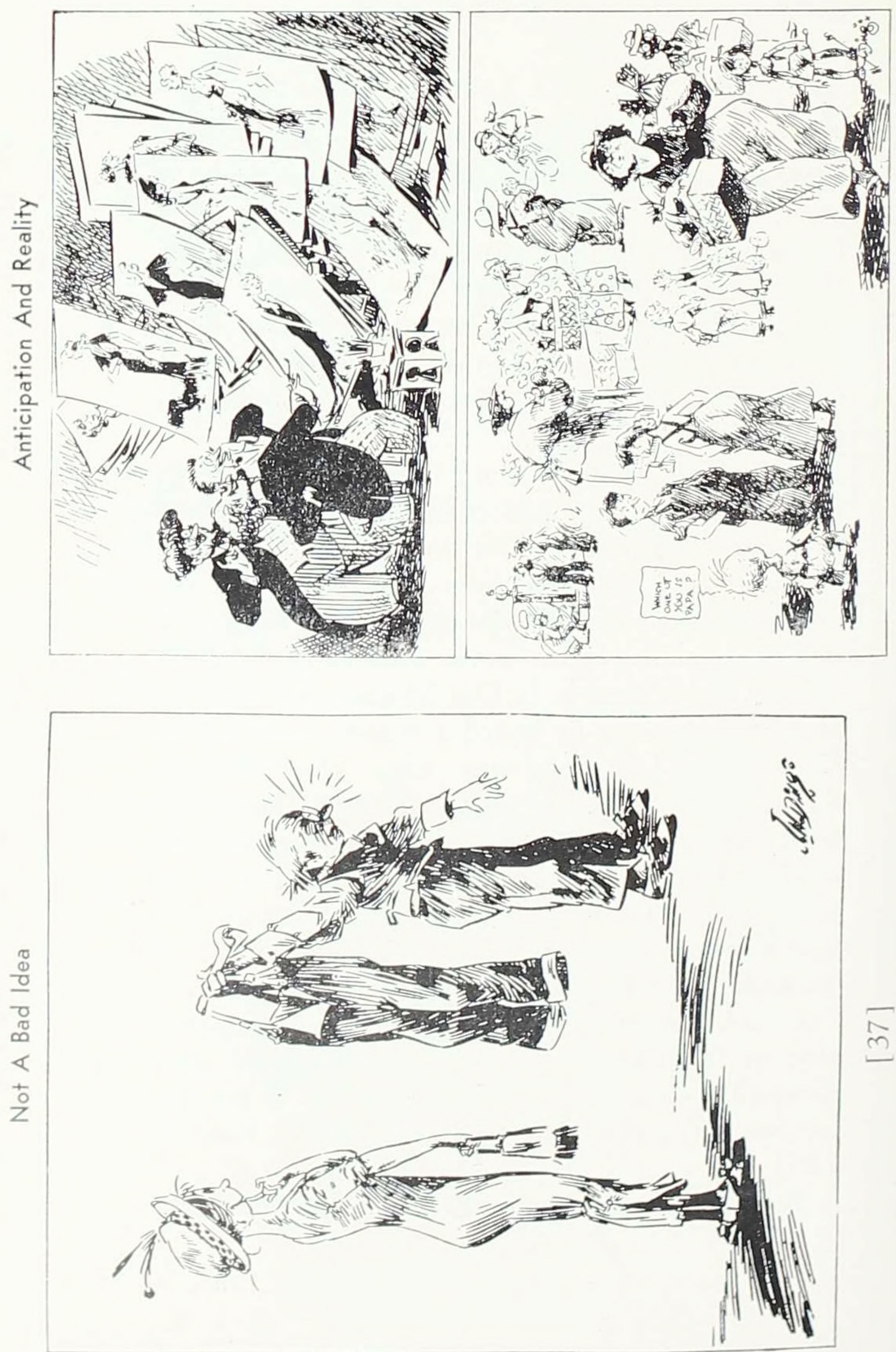

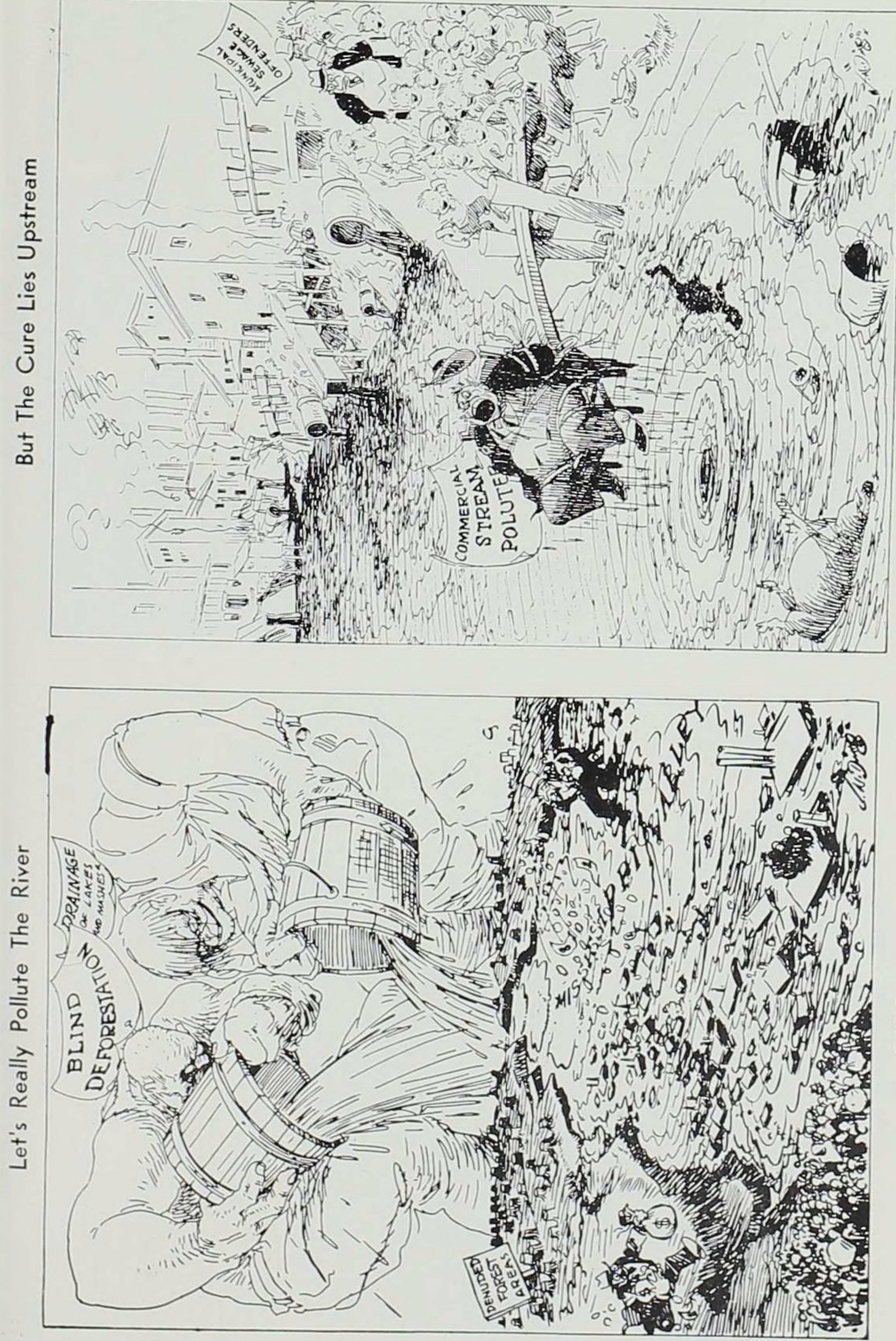

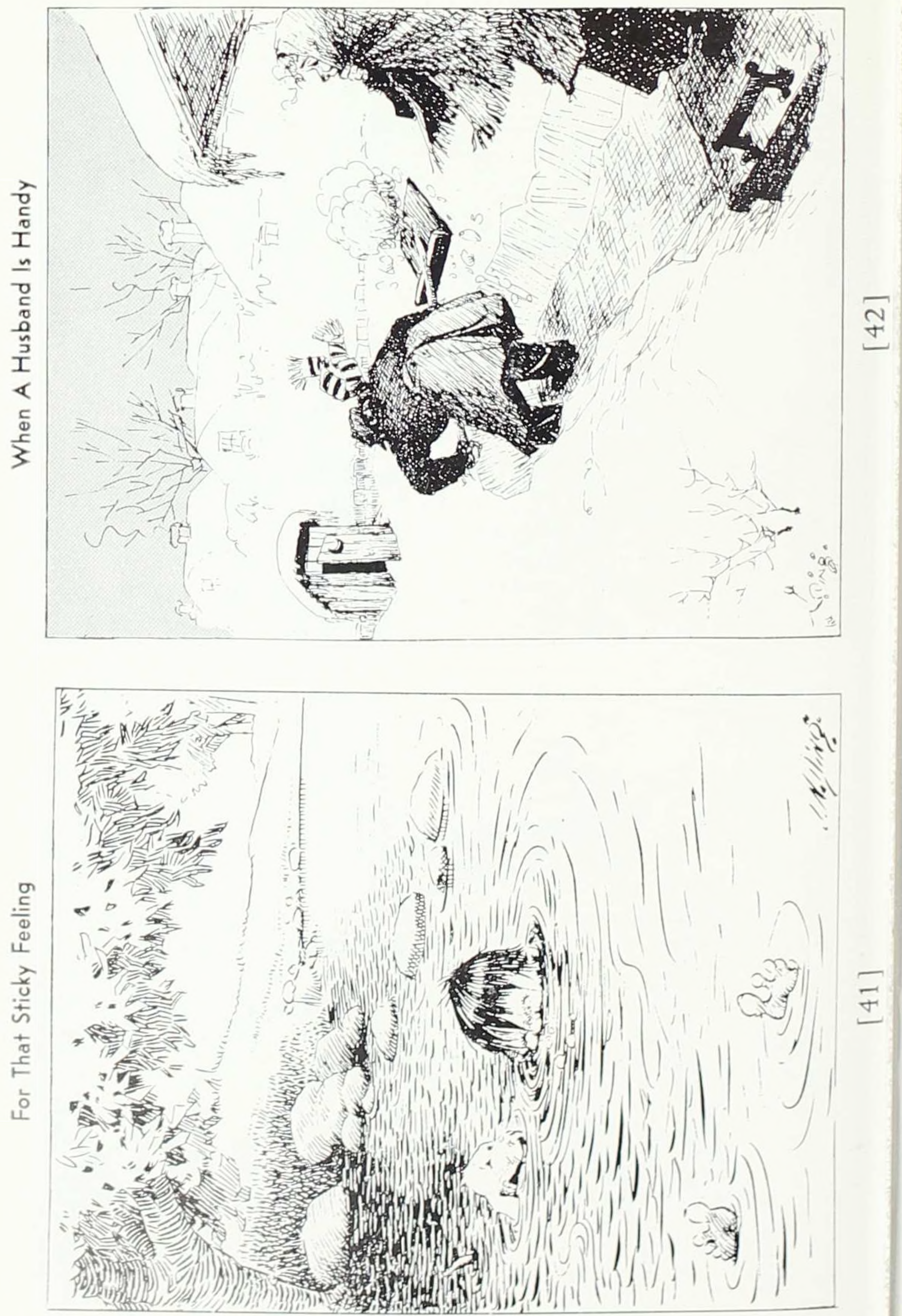

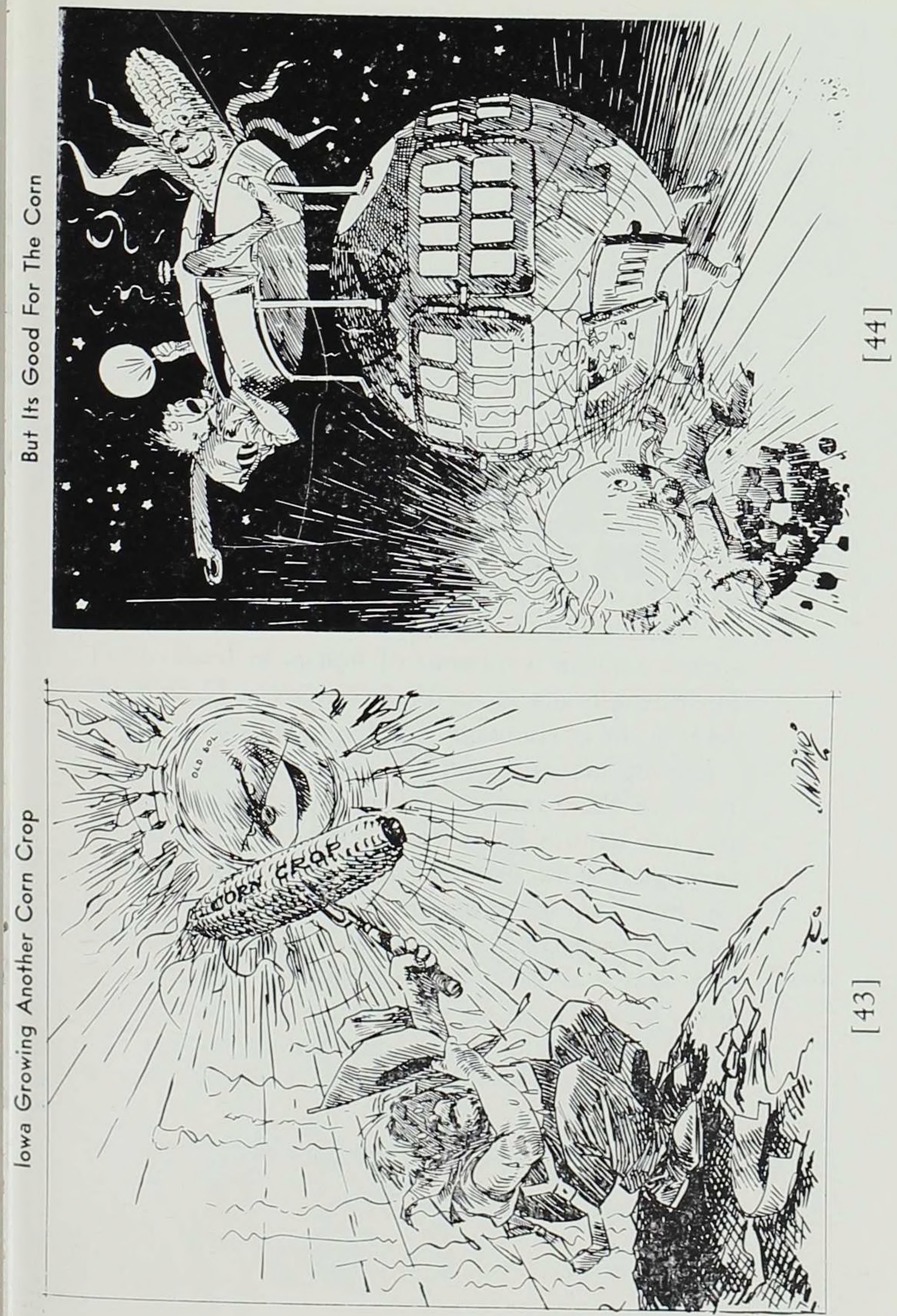
"came a long way." This fact is illustrated by a cartoon drawn early in his career, 1909, [37] and one in the latter part of the 1940's. [38]

Ding was almost as famous as a conservationist as a cartoonist. He drew more than 100 cartoons urging conservation practices in the various fields. He was in Washington for two years in the 1930 's, furthering the preservation of wild life. Al most all of his conservation cartoons are as pertin ent now as they were in the 1930's, when he drew most of them. The two shown here are representative of the many. The one at the left appeared in 1927, [39] at the time of the great Mississippi flood. The other appeared first in 1937. [40]

Called "The Bathroom Pair," these cartoons appear now in a number of homes in Iowa. [41] They usually are located appropriately. Ding drew them in the early teens. [42]

During his later years, Ding had cartoons dealing with the attempts of Congress and the president to handle huge corn crops so the farmers would not suffer from resulting low prices. But in the first two decades his consideration was of weather conditions - and he, like all Iowa, believed that heat was what was needed to bring a good crop. [43] There never was, in those years, any worry about huge crops depressing prices. The cartoon at the left was drawn in 1916, the other in 1919. [44]

Ding, by his cartoons, was making a record of 

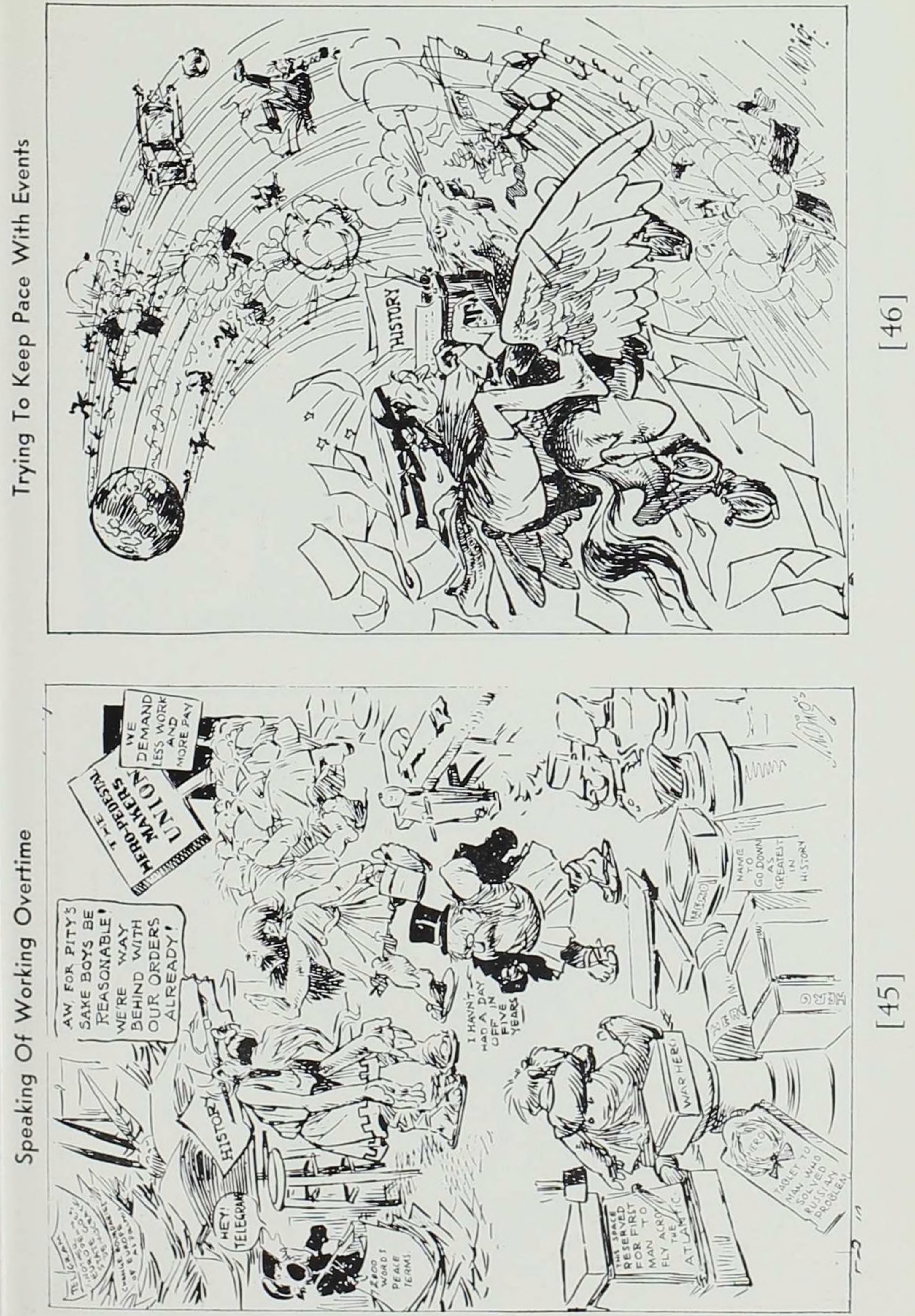

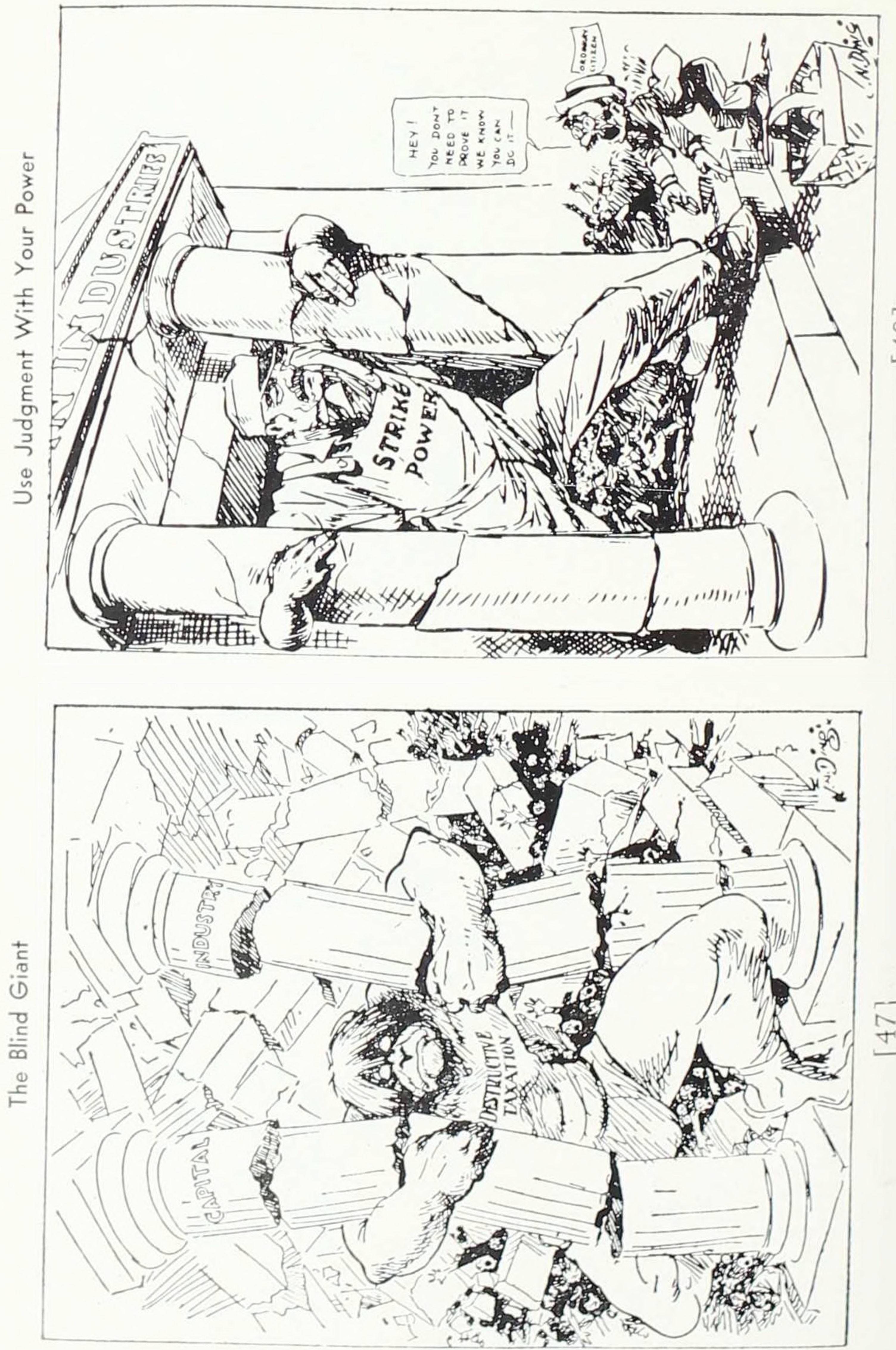

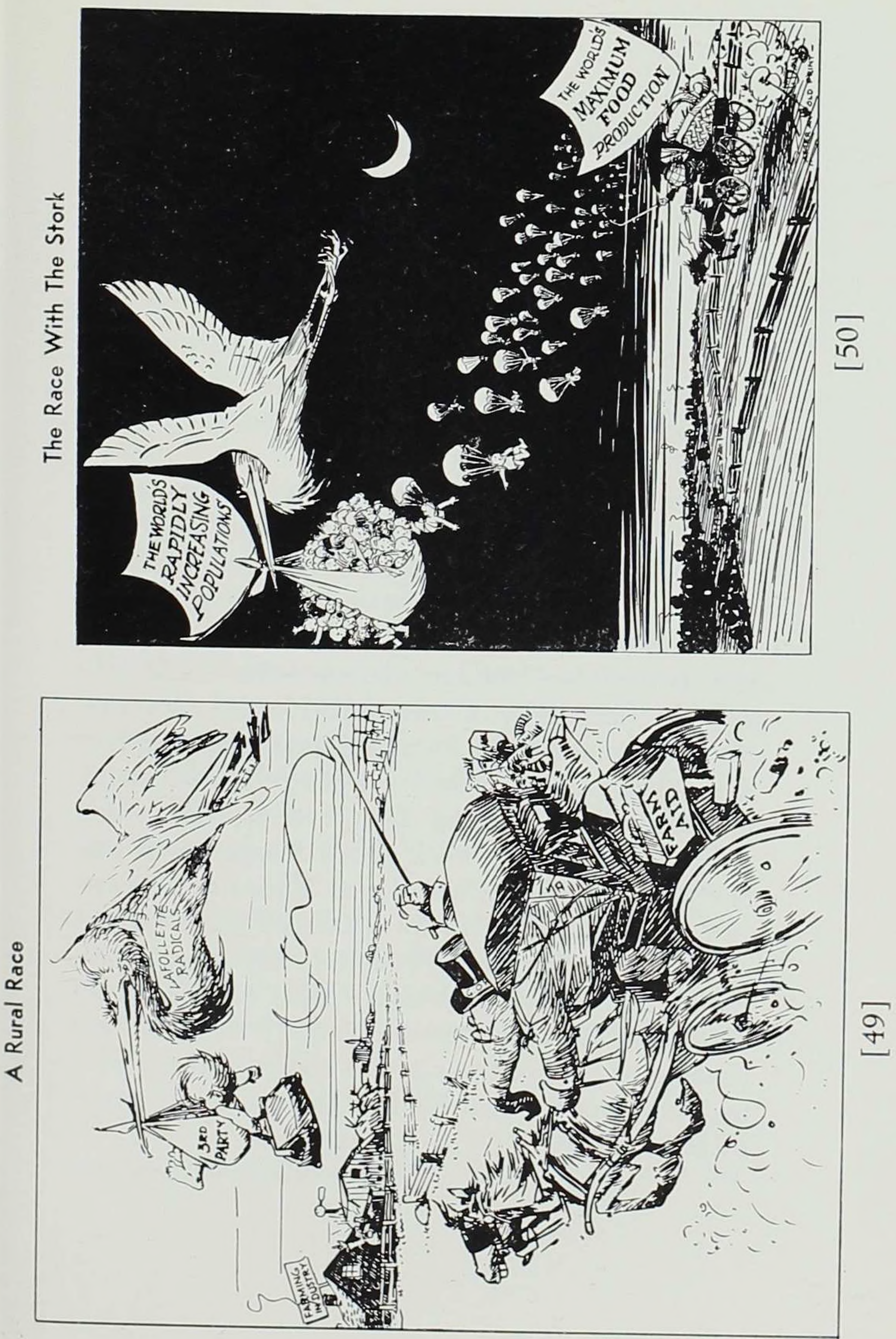
the history of the first half of the century. [45] This resulted, probably, in his preoccupation with history - "feeling sorry for history"- -as it were. [46] His light-hearted touch appeared in two cartoons drawn near the close of World War I-both in 1917.

These cartoons, so very much alike, were drawn a decade apart. That at the left came from Ding's drawing board in the 1920's, [47] and that on the right in the late 1930's. [48]

These cartoons, as Ding's note at the bottom of the one at the right recalls, are from an old print. That at the left [49] depicted the effort of Rob ert M. La Follette of Wisconsin to establish his Third Party - in 1924-which he called Progres sive, before the Coolidge administration could satisfy the farmers with farm aid. He did establish his party, and he was its presidential nominee, but the ticket carried only La Follette's Wisconsin in the election. During Ding's time there were three Third Parties, each called Progressive: the one noted here-the one which Theodore Roose velt organized in 1912 in a vain effort to be re elected president, and that in 1948-which had Iowa's Henry Agard Wallace as its nominee. The cartoon at the right was drawn in 1948, at the beginning of the post-war period in which the world began to worry about feeding the increasing populations. [50]

JOHn M. HEnRY 